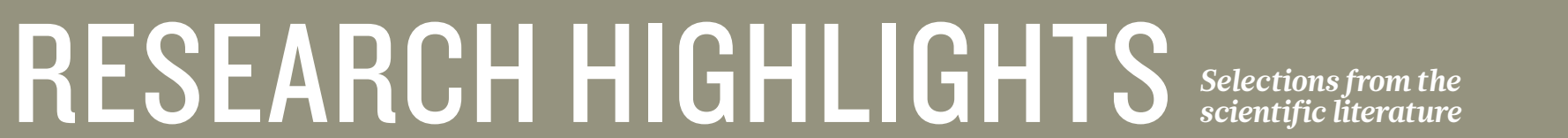

AGRICULTURAL ECOLOGY

\section{Pesticide link to wild-bee declines}

A class of pesticide called neonicotinoids has been associated with the decline of wild-bee species across the United Kingdom.

Small and short-term studies have shown that the chemicals - which were first used widely in the country in 2002, before being placed under a 2 -year moratorium by the European Union in 2013 - can harm bee reproduction. To look for longterm effects at the population level, Ben Woodcock at the NERC Centre for Ecology and Hydrology in Wallingford, UK, and his colleagues compared maps of pesticide use on oilseed rape (canola) crops with surveys of 62 wild-bee species across the United Kingdom from 1994 to 2011. They found correlations between neonicotinoid exposure and population declines in bees that forage on the crops, and even in some that don't.

The team estimates that the chemicals are linked to population losses of more than $10 \%$ for 24 bee species.

Nature Commun. 7, 12459 (2016)

\section{BIODIVERSITY}

\section{New lizards under threat}

Recently discovered lizard species tend to be smaller, are more often nocturnal and are at greater risk of extinction than those described previously.

Scientists have been identifying new lizard species at an astonishing rate - with a more than $30 \%$ increase in species number recorded since 2000. To find out what these animals have in common, Shai Meiri at Tel Aviv University in Israel studied data on the biology and geography of all

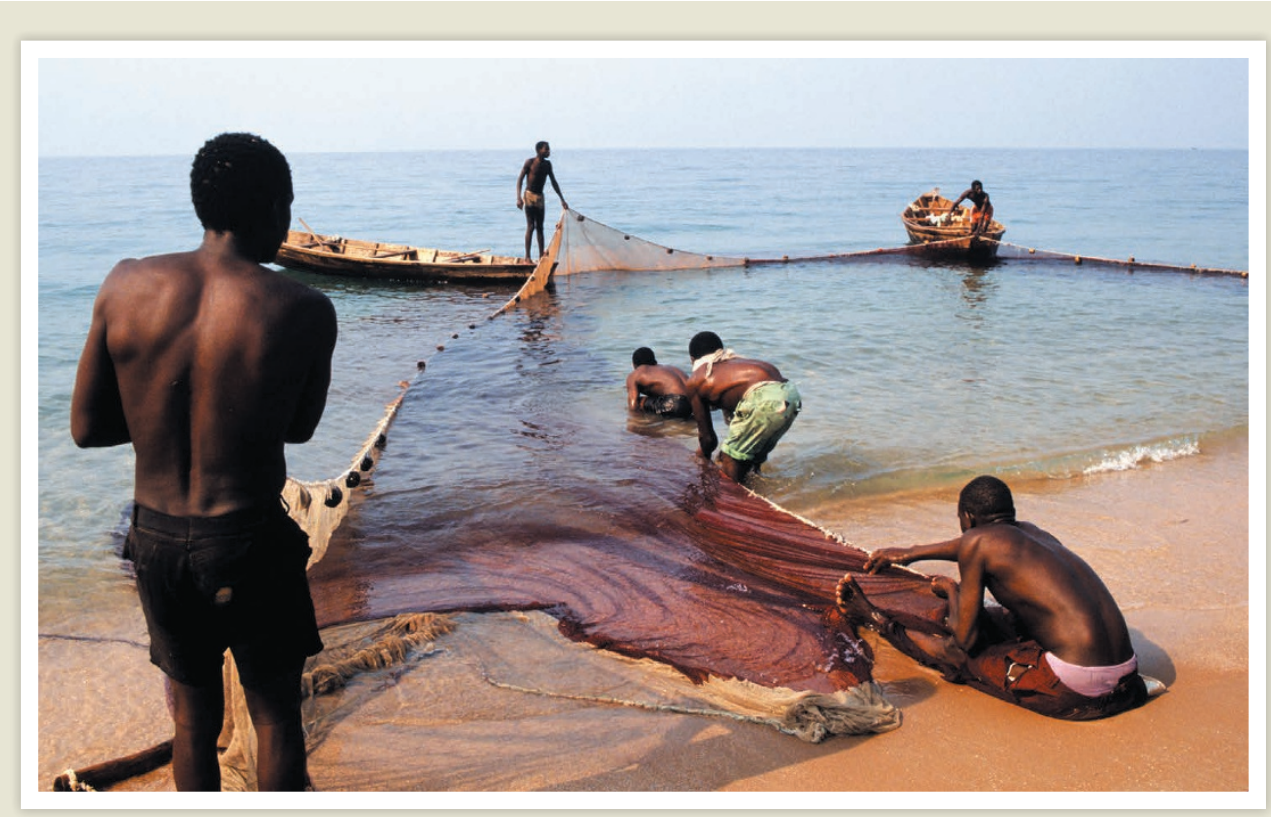

CLIMATE CHANGE

\section{Warming drives down lake life}

Rising temperatures have lowered fish numbers in one of Africa's great lakes, threatening food sources vital to local people.

Andrew Cohen at the University of Arizona in Tucson and his colleagues analysed sediments and fossils from Lake Tanganyika (pictured) to infer water temperatures and estimate species abundance going back over 1,500 years. They found population declines in fishes, molluscs and plankton that pre-dated commercial fishing, but correlated with sustained warming and falling algal production during the past 150 years.

Warming reduces the mixing of nutrient-rich deeper waters with oxygen-rich shallow waters, limiting the growth of plankton - an important food source for many fishes. Reduced mixing also lowers the area of oxygenated water at the bottom of the lake, threatening numerous fish and invertebrate species.

Proc. Natl Acad. Sci. USA http://doi.org/bnqk (2016)

\section{6,321 lizard species known} in mid-2015. He found that species described this century tended to be small and to have limited geographical ranges explaining why they remained undiscovered for so long. Nearly $40 \%$ of these lizards were geckos, and $37 \%$ were nocturnal.

New species were more likely to have declining populations and face extinction, meaning that many species may be lost soon after — or perhaps even before being described, Meiri warns. J. Zool. 299, 251-261 (2016)
CELL BIOLOGY

\section{CRISPR switches cell types}

By activating a suite of genes using the gene-targeting tool CRISPR-Cas9, researchers have turned connective-tissue cells called fibroblasts directly into neurons.

Directly reprogramming cells from one identity to another could one day provide abundant material for disease research or therapies. But scientists face a technical challenge - keeping genes required for the new identity switched on for a lengthy period of time. To resolve this, Charles Gersbach at Duke University in Durham, North Carolina, and his colleagues used a CRISPR-Cas9-based system to activate three genes, converting mouse embryonic fibroblasts into neuronal cells and sustaining gene activation throughout the process.

The technique could provide a way to reprogram cells without having to insert genes into the genome. Cell Stem Cell http://doi.org/ bn22 (2016) 